\title{
Is there a "compensation culture" in contemporary Russia? The role of liability insurance, non-pecuniary damages, and legal profession in personal injury litigation
}

OÑati Socio-Legal Series Volume 11, Issue 2 (2021), 556-588: “ToO Much Litigation?”: Facts, REASONS, CONSEQUENCES, AND SOLUTIONS

DOI LINK: HTTPS://DOI.ORG/10.35295/OSLS.IISL/0000-0000-0000-1141

RECEIVED 03 SEPTEMBER 2019, ACCEPTED 29 JUNE 2020

\section{TIMUR BOCHAROV*}

\section{Abstract}

This article explores current trends in personal injury litigation in Russia compared with the common law countries (the UK and US). In contrast to the British and American situation, there is no concern about the problem of "compensation culture" or "litigious behaviour" in Russian public discourse. The number of personal injury cases considered by Russian courts is not particularly high despite the growing number of accidents. This state of affairs can be explained by the influence of the Soviet culture of tort law. The most visible areas of the Soviet impact addressed in the article are liability insurance, non-pecuniary damages, and the legal profession. The article demonstrates the specificity of the Russian approach to these issues. The research is based on the analysis of judicial decisions on personal injury cases, court statistics, and expert interviews with personal injury lawyers. The findings are discussed from a historical and comparative perspective.

\section{Key words}

Personal injury; liability insurance; Soviet tort law; compensation culture; nonpecuniary damages

\section{Resumen}

Este artículo examina tendencias actuales en litigios sobre daños personales en Rusia, en comparación con los países con derecho consuetudinario (Reino Unido y Estados Unidos). A diferencia de los casos británico y estadounidense, en el discurso público de Rusia no se repara en el problema de la "cultura de la compensación" o "comportamiento litigioso". El número de casos de daños personales en los juzgados

\footnotetext{
* Timur Bocharov, MA in Sociology (European University at St Petersburg), LLM (University of Manchester), PhD Candidate (University of Kent), Affiliated Researcher (Institute for the Rule of Law, St Petersburg). Contact details: Kent Law School, Eliot College Extension, University of Kent, Canterbury, Kent, CT2 9ER, UK. Email address: T.I.Bocharov@kent.ac.uk
} 
rusos no es especialmente algo, a pesar del número creciente de accidentes. Este estado de cosas se puede explicar por la influencia del derecho soviético sobre responsabilidad civil. Las áreas más evidentes de influencia soviética que se tratan en el artículo son los seguros de responsabilidad, los daños inmateriales y la profesión jurídica. El artículo demuestra la particularidad del enfoque ruso a estos temas. La investigación está basada en el análisis de decisiones judiciales en casos de daños personales, estadísticas judiciales y entrevistas con abogados especializados en daños personales. Los hallazgos se exponen desde una perspectiva histórica y comparativa.

\section{Palabras clave}

Daños personales; seguro de responsabilidad; derecho soviético sobre responsabilidad civil; cultura de la compensación; daños inmateriales 


\section{Table of contents}

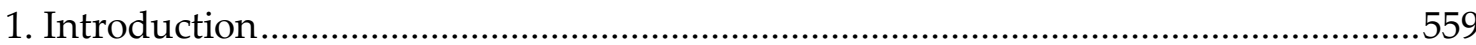

2. Personal injury litigation in Russia: Legislative basis and court statistics..................561

3. Liability insurance and social security in the Soviet Union and contemporary Russia

4. Non-pecuniary damages: Current judicial approach

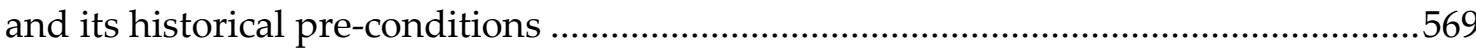

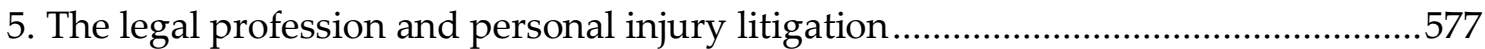

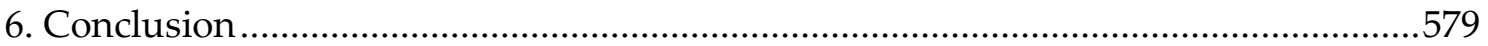

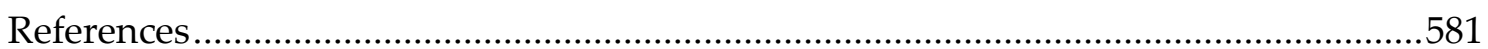

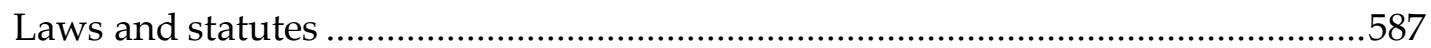

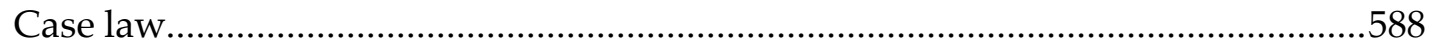




\section{Introduction}

There is a long-term debate within the English-speaking media, political circles, and academia regarding the supposed problem of a so-called "compensation culture" in the sphere of personal injury litigation. This term has a negative connotation. The public in the US and UK is concerned that the number of personal injury claims being brought is excessive and that awards for even minor injuries are unreasonably large. A further concern is the suggested increase in the readiness of claimants to seek such compensation. Pain and suffering damages are at the centre of attention since they constitute a significant part of damages awarded in personal injury cases. ${ }^{1}$ In the US, the quantum of these damages is subject to jury decision which is frequently criticised for being spontaneous and emotionally conditioned. The UK situation is slightly different in the sense that a professional judge awards general damages, though within the brackets provided by the Judicial College Guidelines (JCG). However, despite the availability of these guidelines based on precedents, they leave sufficient space for judges to exercise discretion in awarding general damages. Finally, the term "compensation culture" involves an active role of personal injury lawyers and claim management companies overzealously taking cases on a conditional or contingency fee basis.

There are qualitative and quantitative studies showing that the problem of compensation culture is exaggerated in the US (Engel 2016) or the UK (Lewis et al. 2006). This does not stop politicians and the media from supporting the same discourse about compensation culture. Personal injury litigation is to a large extent a political issue in the US and UK which attracts attention of the two major stakeholders: insurance companies and personal injury law firms. The insurance companies attempt to limit personal injury damages (especially for minor injuries), consider a significant part of such claims to be fraudulent or exaggerated, while personal injury lawyers are understandably interested in a constant increase of compensatory awards.

The situation with personal injury litigation in Russia is the converse. The available statistics demonstrate that the number of serious accidents is not less or even higher in Russia than in the UK or US² but the number of personal injury cases is relatively low, and there is a surprising lack of any discussion on compensation culture there. In fact, it is the low value of human life and health reflected in judicial awards that are seen as a social problem. ${ }^{3}$ The present article aims to provide a number of possible explanations for this situation using historical and comparative perspectives. Tort law is deeply rooted in the social context, including cultural attitudes and values of legal professionals

\footnotetext{
${ }^{1}$ In the UK, pain and suffering damages constitute about $2 / 3$ in the majority of claims which are for minor injuries (Lewis and Morris 2012); in the US, this proportion comprising approximately $60 \%$ of personal injury damages (Vidmar et al. 1998).

2 For example, according to the World Health Organization statistics 2016, estimated road traffic death rate per 100,000 inhabitants was 18,0 in Russia compared with 12,4 in the US and 3,1 in the UK (see https://apps.who.int/gho/data/node.main.A997, accessed 23 June 2020).

${ }^{3}$ For example, the resolution after the recent round table at the All-Russia Civil Forum 2019 (OGF 2019) emphasised two major problems with compensation for pain and suffering and wrongful death in Russian. The first problem is the low level of awards. The second problem is inconsistency and unpredictability of awards. Among the participants were representatives of the Bar, academia, the Constitutional Court, ombudsman office, human rights organisations, etc.
} 
and ordinary people (Bussani and Infantino 2015). The claim rates and quantum of damages can be seen as the external manifestation of underlying extra-legal factors. From this perspective, tort law is largely a social convention on what is wrongdoing for which a victim can obtain a remedy, what form of remedy is available and what is the extent of fault and responsibility. The attitudes towards torts and insurance should not be seen as something stable. They can change significantly or preserve features of previous historical periods. Moreover, torts systems have national specific which gives unique characteristics to claiming procedure and dispute resolution. Therefore, in order to better understand current personal injury litigation trends in Russia, it will be productive to explore the Soviet background behind these trends (a diachronic approach) as well as to situate them into a comparative context (a synchronic approach).

The current situation with personal injury cases is mostly a legacy of the Soviet legal system. Tort law was one the less reformed area of Russian civil law in the 1990s. This is particularly evident in the approach to damages and insurance. The article demonstrates that during Soviet rule monetary compensation for pain and suffering was considered as a bourgeois legal institute incompatible with socialist values. Therefore, this remedy was not available throughout the entire Soviet history. The remnants of this restrictive approach are still evident in the Russian tort system today. The average level of awards is extremely low. There is also an explicit legislative exclusion of pain and suffering damages from compulsory insurance for road traffic accidents and industrial accidents. The focus on Soviet legal history therefore can shed light on the current problems with personal injury cases.

The article also aims to contribute to a broader debate on litigation behaviour in civil cases. The current tendency towards the decline of court disputes led to the phenomenon of "vanishing trials" (Dingwall and Cloatre 2006), "disappearing trials" (Kritzer 2004) or "litigation avoidance culture" (Blankenburg 1997). This trend is the most evident in personal injury cases where insurance companies, being "repeat players" (Galanter 1974), try to settle most claims in order to minimise their litigation costs. Personal injury lawyers, for their part, treat settlement with the insurance company as the most optimal outcome of the case. It is extremely unlikely that a claim will be submitted if there is no insurance coverage, except for some rare cases when claimants seek "blood money" rather than compensation (Baker 2001). These trends might characterise Anglo-Saxon context but far from being relevant to personal injury litigation in Russia. Indeed, the number of court case on personal injuries is also low there, albeit for different reasons which are discussed in detail below.

The structure of the article is as follows. The first section aims to describe the basics of the Russian tort system and current tendencies in personal injury litigation, drawing on the available official statistics, interviews with legal practitioners, ${ }^{4}$ and qualitative

\footnotetext{
4 There have been collected 6 expert semi-structured interviews with British and Russian personal injury lawyers as a part of the author's dissertation project. The necessary ethical approval has been obtained from the University.
} 
analysis of judgments. ${ }^{5}$ Particular attention is paid to road traffic accidents and workplace accidents for several reasons: a) these are the most massive types of personal injury cases; b) RTA is the area where a strict liability regime widely operates in Russia, in contrast to common law countries; c) social security approach to work-related accidents inherited from the Soviet past still prevails in Russia. In the second section, I analyse the role of liability insurance for personal injuries in Russia that differs substantially from its role in the UK and US. In the third section, I focus on the issue of pain and suffering damages and their problematic position throughout Russian history analysing academic debates and relevant judicial practice. Finally, the fourth section is dedicated to the involvement of lawyers in personal injury litigation. In conclusion, I discuss the relevance of the socialist legal heritage for the current configuration of personal injury litigation in Russia drawing, where possible, parallels with other postsocialist Eastern-European jurisdictions.

\section{Personal injury litigation in Russia: Legislative basis and court statistics}

One of the main differences between the common law and civil law is the existence of separate torts in the former and the principle of the so-called general delict in the latter (Zweigert and Kötz 1998). This distinction can be fully applied to the Russian tort law. In the Russian civil legislation, there cannot be found a system of separate torts like in the UK or US, ${ }^{6}$ but there is a general institution of liability for causing harm (Art. 1064 of the Russian Civil Code). Despite the serious changes in Russian civil law after the fall of the Soviet regime and transition to a market economy (contract law, banking law, intellectual property law, insurance law and other areas were literally built from the ground up), there were no significant reforms in the area of tort law. The two most distinctive features of the Soviet tort law remain practically unchangeable - the uncommon distribution of the burden of proof (a presumed fault of the tortfeasor) and strict liability of the sources of increased danger (Lee 2014).

The reverse burden of proof seems to be a unique feature of Russian tort law and is rarely found elsewhere. This allows some legal scholars to talk about a general "quasi-strict" liability regime in all tort cases in Russia (Brüggemeier 2011, p. 16). In other jurisdictions, this principle can be applied in certain cases as an exemption ${ }^{7}$ but not as a general rule like it is encapsulated in the Russian Civil Code. The historical roots of this rule lie in the first Soviet Civil Code of 1922 which provisions on tort law were not based on the fault principle. There were strong ideological reasons for this attempt to move towards a non-

\footnotetext{
5 The data consists of 674 judgments of Russian regional appeal courts taken from the legal database Consultant Plus (http://www.consultant.ru) and 187 judgments of the Court of Appeal and the High Court (England and Wales) taken from the legal database Westlaw UK (https://westlaw.co.uk). The relevant judgements were searched by the keywords "personal injury", "pain and suffering damages", "moral damages". The collected texts were coded and analysed with the assistance of NVivo software.

6 The British and American tort systems have significant differences despite being both common law jurisdictions. For example, see comparative articles by Atiyah (1987) or Kritzer (1991). However, for the purposes of this text they are considered together since they share the most basics characteristics concerning liability insurance, non-pecuniary damages and legal profession which are equally different from the Russian situation.

${ }^{7}$ For example, the doctrine res ipsa loquitur in American and English tort law when the context of the incident makes the fault of the defendant so evident ("things speak for themselves") that it becomes his/her procedural obligation to prove its absence.
} 
fault system such as an aspiration to distinguish a newly born Soviet tort law from individualistic fault-based tort law of bourgeois countries (Rudden 1967). Article 403 of the Civil Code 1922 introduced the norm on general delict which was very similar to strict liability. However, the Soviet judicial practice could not absorb this principle and started to interpret the norm from the fault perspective (Gray 1964). This position of the Soviet judiciary was later reflected in the new Civil Code of 1964 in which the fault principle was explicitly re-established. Nevertheless, the residuals of the previous nonfault approach survived in the principle of tortfeasor's presumed fault.

The second distinctive feature of Russian tort law is strict liability for accidents caused by sources of increased danger. The meaning of the concept "sources of increased danger" is extremely broad. Although Article 1079 of the Russian Civil Code provides some examples such as a motor vehicle, electric energy of high voltage, atomic energy, explosives, potent poisons, construction activity, this list is non-exhaustive. The court can interpret other means of causing harm as sources of increased danger. The only available defence for the owner of the source of increased danger is to prove force majeure circumstances or the explicit intention of the injured to suffer harm (for example, a suicide attempt). The extension of strict liability to such a mundane thing as a motor vehicle seemed very peculiar to Western scholars. Some of them were ready to read political implications into this principle treating it as an additional burden for a relatively wealthy and rare social group of car owners (Hazard 1952, Barry 1979). In 1960-70s, it was suggested that the strict liability rule will be abolished with the increase of the persons-per-vehicle ratio (Rudden 1967, Osakwe 1979).

These predictions, however, did not become a reality. Indeed, the use of a private motor vehicle has expanded substantially after the collapse of the Soviet Union. It should be noted that there were strong ideological constraints which precluded the mass consumption of cars during the Soviet era. Private cars were seen as symbols of a bourgeois style of life and initially were distributed among Soviet citizens rather than sold directly. It is only after the establishment of the national automobile industry in the 1970s the consumption of motor vehicles started to grow. However, as Lewis Siegelbaum demonstrates in his study of the Soviet "car culture", the interests of motor vehicle owners were not taken into account by the state event when mass automobile production became possible (Siegelbaum 2008). The quality of cars, road infrastructure and repair services were far from adequate in the Soviet Union. The transition to the market economy made import cars and related services available for Russians which led to the wider use of private motor vehicles. However, despite a dramatic increase in the ratio of car owners in Russia, ${ }^{8}$ the norm on strict liability remains unchanged.

The reverse burden of proof and strict liability regime are legal mechanisms set explicitly in favour of claimants. Taking into account this strong pro-claimant approach of Russian tort law, it seems reasonable to expect the number of personal injury claims filed in courts to be high. However, that is not the case as the official court statistics

\footnotetext{
8 Though, the ratio is still smaller than in Western countries. For example, according to the United Nations Economic Commission for Europe statistics, the ratio was 271 vehicles per 1,000 Russian citizens in 2012. For comparison, it was 451 in the UK and 354 in the US in the same year (see https://w3.unece.org/PXWeb/en/Charts?IndicatorCode=44).
} 
demonstrate. ${ }^{9}$ The number of court decisions on personal injury and wrongful death claims (iski o vozmeshhenii vreda, prichinennogo uvech'em $i$ smert'ju kormil'ca) is not particularly high showing the tendency to drop in the recent decade: from 9,478 court decisions in 2007 to only 2,142 in 2019.

TABLE 1

\begin{tabular}{|l|r|r|r|}
\hline & Court decisions & \multicolumn{1}{|c|}{ Terminated cases } & Cases resolved by ADR \\
\hline $\mathbf{2 0 0 7}$ & 9,478 & 1,590 & - \\
\hline $\mathbf{2 0 0 8}$ & 8,059 & 1,109 & - \\
\hline $\mathbf{2 0 0 9}$ & 6,620 & 853 & - \\
\hline $\mathbf{2 0 1 0}$ & 6,150 & 762 & - \\
\hline $\mathbf{2 0 1 1}$ & 5,765 & 686 & - \\
\hline $\mathbf{2 0 1 2}$ & 4,955 & 626 & - \\
\hline $\mathbf{2 0 1 3}$ & 4,864 & 500 & - \\
\hline $\mathbf{2 0 1 4}$ & 4,781 & 540 & - \\
\hline $\mathbf{2 0 1 5}$ & 4,431 & 473 & 2 \\
\hline $\mathbf{2 0 1 6}$ & 4,780 & 497 & 3 \\
\hline $\mathbf{2 0 1 7}$ & 3,865 & 392 & 1 \\
\hline $\mathbf{2 0 1 8}$ & 2,531 & 354 & 1 \\
\hline $\mathbf{2 0 1 9}$ & 2,142 & 254 & - \\
\hline
\end{tabular}

Table 1. First instance court decisions on personal injury and fatal accident claims in Russia in 2007-2018.

The column "terminated" (prekrashheno) be treated as a rough equivalent to the proportion of settled cases since the main legal grounds for terminating a case without a trial, according to Russian Civil Procedural Code (Art. 220), are as follows: a) settlement agreed between parties and confirmed by the court; b) claimant refused to proceed further with the claim which in most cases would mean that the defendant had paid out damages voluntary; c) non-civil character of the case so it is subject to consideration by a court with different competency (commercial, administrative, etc.), there is a decision of the arbitration tribunal, or the claimant died. However, the last group of reasons is extremely rare. The rough estimation of settled ( terminated) cases, therefore, is around $10 \%$.

This proportion is much lower compared to the situation in other jurisdictions where only a minimum percentage of personal injury cases end up in a trial. As for example, Laurence Ross mentioned in his socio-legal study of insurance claims adjustments, $98 \%$ of personal injury claims are settled out of the trial in New York (Ross 1980, p. 4). This figure might be even larger in less litigious parts of the country. More recent statistics show a continuity of this general pattern. There were, for example, only $2 \%$ of tort cases concluded by a trial in the US in 2003. ${ }^{10}$

In the UK, the vast majority of personal injury cases are also settled out of court. Moreover, it is normal to settle a personal injury case even if formal court proceedings were initiated. For example, according to the UK Pearson Commission report, $86 \%$ of

\footnotetext{
${ }^{9}$ Hereinafter Russian court statistics are taken from the Judicial Department official website (Summary Statistics on the Activities of Federal Courts of General Jurisdiction and Justices of the Peace, available at: http://www.cdep.ru/index.php?id=79 accessed on 23 June 2020).

10 Statistics provided by the U.S. Department of Justice, Bureau of Justice Statistics. Website: https://www.bjs.gov/index.cfm?ty=tp\&tid=451\#federal (accessed on 23 June 2020).
} 
personal injury was settled out of court, $11 \%$ were settled before the trial was scheduled, $2 \%$ were settled after the trial was scheduled whereas the rest $1 \%$ of cases were settled just before or during the trial (Cane 2018). There is no reason to think that this proportion of settled cases has been changed substantially in the UK since the publication of the Pearson report in 1978. This statistic fits with the general decline of trials over the last decades in the UK. The vast majority of civil cases, not only involving personal injuries, are solved by concluding pre-trial settlements between parties.

There are, of course, institutional and procedural differences between the approaches to settlement in the UK and the US ${ }^{11}$ but the result is more or less the same. The involvement of insurance companies makes trials exceptional in personal injury cases in both countries. The popularity of settlements in Western countries can be explained by financial and organisational interests of the insurance companies. But it also implies some clear benefits for claimants. The survey of accident victims shows that the impact of court proceedings on their condition was more negative than an out-of-court claiming procedure (Cotti et al. 2004). Settlements make it possible for both parties to avoid court proceedings and therefore to save time, money, and nerves.

This is not the case, though, in the Russian context. The very necessity of participating in a trial in order to obtain moderate compensation does not contribute to the victims' recovery, rather the opposite. The prospect to go through the court proceedings discourages a large number of victims to claim pain and suffering damages even if they are entitled to that. This is compounded by the generally low opinion of courts prevailing in Russian society. ${ }^{12}$ According to Olga Vakina, a lawyer for the Union of Pedestrians, this results in the situation when victims, "exhausted after hospitals prefer not to mess with the court, especially if they understand that they suffered a 'light damage'" (Vakina, quoted in Lenta 2019). ${ }^{13}$ Therefore, a certain proportion of accident victims are not compensated. The victims who suffered minor personal injuries, as well as the members of the most economically vulnerable social groups who cannot afford legal costs, are more likely to be in this category.

Alternative dispute resolution (mediation) could improve this imbalance but it is very uncommon in Russia. There were only six personal injury and fatal accident cases in 2016-2018 resolved through the mediation procedure (spory, uregulirovannye putem provedenija procedury mediacii). It must be noted that mediation is a relatively recent legal institution in Russia completely unfamiliar to the Soviet civil procedure. The first statute on alternative dispute resolution was implemented only in 2010 (Federal Law N 193-F). The implementation of this act gave rise to many hopes among legal practitioners. It was expected that this innovation will facilitate the amicable settlement of civil disputes. However, it turned out that parties and the judiciary are not particularly interested in using the new legal mechanism. The reluctance towards mediation can be probably a part of the Russian court culture where the excessive control of judges over the court

\footnotetext{
${ }^{11}$ For example, lawyers are more involved in settlement negotiations in England compared to the US where $78 \%$ are settled directly with the victim (Kritzer 1991, p. 416).

12 According to the survey conducted by the Fund of Public Opinion (FOM) in 2018, only 24\% of respondents assessed the work of Russian judicial system positively, and only 31\% of them were prepared to bring their claim to the court while 57\% treated it as a last resort (see FOM 2018).

${ }^{13}$ All translations from Russian are by the author except where noted otherwise.
} 
procedure is still evident despite some moves towards a more adversarial system in post-Soviet civil litigation. Mediation, in these cases, can be treated as a risk. "Even if a judge is intrigued by mediation, she may shy away from promoting it out of fear of losing control over her docket" (Hendley 2014, p. 451). However, a more practical explanation would refer to extremely low legal costs in the Russian courts compared to British or American courts. The cheapness of Russian justice does not provide any incentives for using alternative dispute resolution mechanisms. The only areas where mediation started to be used to a limited extent are labour disputes, family disputes, and commercial disputes between small and medium companies (Davydenko 2013). Personal injury cases, as statistics show, are far from falling into this category.

Perhaps, the only area where settlements can be found more or less regularly is industrial accidents. There is a well-established practice of industry branch agreements between companies and trade unions in which a fixed amount of compensation for pain and suffering is defined. This approach is normally adopted by those companies where the risk of work accidents and occupational decease is the highest. This category includes nuclear, asbestos, metal or coal industry, as in the case below.

In this case, the Industry Agreement and the Collective Agreement concluded between the employees of Siberian Anthracite CJSC and Siberian Anthracite CJSC determine the procedure for compensatory payments to employees, the legal nature of which is aimed at compensating non-pecuniary damage in connection with the identification of occupational disease in an indisputable manner in the prescribed amount. In this connection, the trial court had no reason not to recognize the lump-sum payment made by $\mathrm{T}$. as compensation for non-pecuniary damage caused by an occupational disease in the workplace. (Novosibirsk Regional Appeal Court, 1 August 2017, Case n 337340/2017)

The payments usually consist of several average salaries in the industry or concrete salaries of the injured which multiply on the coefficient based on incapacity degree. The injured worker has an option to take this moderate compensation and abandon the claim or submit a claim to the court and potentially obtain higher compensation, though not substantially.

The distribution of personal injury claims between categories in Russia is more or less similar to the situation in the UK and the US in terms of the prevalence of RTA cases but the share of work accidents and clinical negligence cases is lesser. 
GRAPH 1

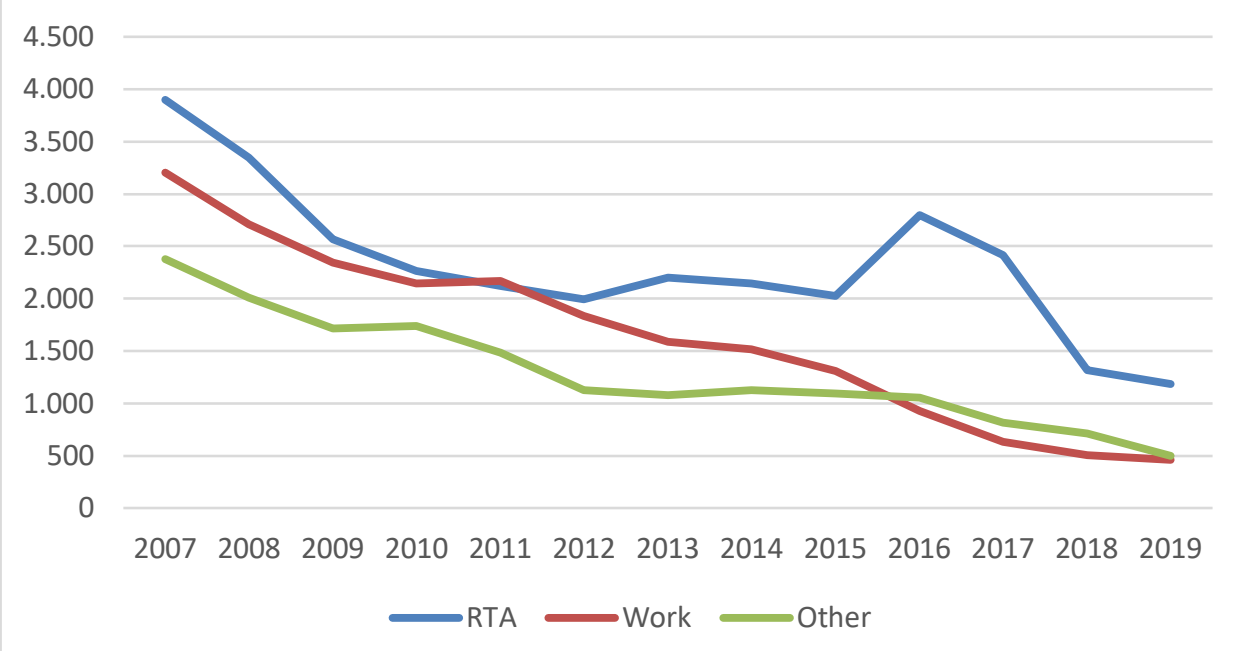

Graph 1 . The number of court decisions on personal injuries and fatal accidents in Russia by categories in 2007-2019.

There were 1,184 decisions on personal injuries and deaths caused by road traffic accidents, 460 decisions on workplace accidents, and 498 decisions on other unspecified cases in 2019. The relatively small number of RTA cases can be explained by the claimant's right to make a direct claim against the insurance company for recovery of payments under compulsory liability insurance. This option became available in 2009 despite a strong lobby of insurance companies against this reform (Hendley 2017, p. 94). These claims, legally speaking, are considered under the category of "disputes over insurance payments" (o vzyskanii strahovogo vozmeshhenija po dogovoru OSAGO) rather than personal injury claims. Indeed, the number of these disputes is large. For example, in 2019, the total number of the decisions on the recovery of insurance payments for RTA was 153,556 but the figure is not broken into car damage and personal injuries. There is also a lack of statistics on the total number of claims filed in insurance companies but did not turn into a court case. There is no institution equivalent, for example, to the Compensation Recovery Unit in the UK where insurance companies are obliged to inform about any submitted claim. Therefore, we can only speculate that the number of claims for personal injuries filed to insurance companies substantially exceed the number of personal injury cases considered by Russian courts.

However, there are potentially a lot of personal injury cases which remain outside insurance coverage. The limit of compulsory car liability insurance is relatively low being 500,000 roubles $(€ 6,457)$ for personal injuries, and this sum does not cover pain and suffering damages (called "moral damages"). Therefore, claimants have to sue defendants directly in order to obtain compensation above the limits as well as pain and suffering damages. The other feature is the lack of compulsory liability insurance against workplace accidents. The social security scheme though is available, but the limits are also low. Importantly, it also does not cover pain and suffering damages. The claimant, again, has to sue the employer directly to obtain compensation above the limit and pain and suffering damages. This makes personal injury litigation in Russia different compared to the UK or the US situation where the absolute majority of personal injury cases involve insurance companies. Taking this into account, the number of personal 
injury cases submitted to Russian courts is much lower than it could be. In order to understand better how this situation could arise, we need to explore the approach to liability insurance and non-pecuniary damages in the Soviet tort law.

\section{Liability insurance and social security in the Soviet Union and contemporary Russia}

In the Soviet period, liability insurance was not available. The general opinion was that liability insurance is an unacceptable way to avoid personal responsibility for wrongdoing (Rudden 1967, Tay 1969). There can be found the same prejudices against liability insurance in Western societies of the 19th century as in the Soviet Union. For example, the possibility of shifting responsibility from the tortfeasor to insurance company was considered immoral and illegal in England in the beginning of the 19th century (Shavell 2004, p. 267, Priel 2014, p. 724). However, with growing industrialisation, third party liability insurance became a basis of the whole tort system. That was not the case in the Soviet Union where liability insurance against car accidents was not available throughout Soviet history. The lack of insurance would make the situation of Soviet drivers harsh, but the absence of general damages partially balanced the requirement to pay compensation personally. Medical costs were also excluded from compensation since all medical services were provided by the State free of charge. It is worth to be mentioned that any insurance market was impossible in the Soviet socialist economy. Therefore, liability insurance could be provided only by the state company which would mean a de facto non-tort compensation scheme administrated by the State. However, this model has not been realised though there was a discussion about the necessity of its implementation for car accidents among liberal-minded Soviet legal scholars.

This restrictive approach to liability insurance started to change only after the collapse of the Soviet Union. The new Civil Code of 1994 for the first time introduced liability insurance as a concept and institution in Russian law (Civil Code, 1994, art. 931). The relevant provisions of the Code imply compulsory and voluntary forms of liability insurance. Nevertheless, the area of application of liability insurance continues to be relatively limited. There were submitted several legislative proposals for implementation of compulsory motor vehicle insurance in the 1990s. And yet, all these attempts for a long time remained unsuccessful. Most of these legislative initiatives had not even reached the adoption stage in the Russian parliament (Shevchuk and Pleshkov 2001). Those rare of them which had reached this stage were blocked by the president's veto (Thompson 1996). For the first time, compulsory motor vehicle liability insurance was implemented in Russia only in 2003 (Law on Compulsory Motor Third Party Liability Insurance, 1 July 2003), much later than in other jurisdictions. ${ }^{14}$

Road accident victims can claim compensation directly from the insurance company. This option is available since Russian insurance law and doctrine recognise victims as primary beneficiaries of compulsory liability insurance, even though the real object of insurance is the interest of the insured in shifting responsibility (Khudyakov 2010).

\footnotetext{
${ }^{14}$ For comparison, compulsory motor vehicle insurance has been in operation in the UK since 1930 (The Road Traffic Act of 1930) and in the US since1925 - first in Massachusetts (The Massachusetts Compulsory Automobile Liability Security Act of 1925) and later in other states.
} 
However, it is not uncommon for insurance companies to delay or refuse payment on the pretext of the absence of sufficient documents (Fogelson 2012). Therefore, there were implemented certain legal mechanisms to address this issue. First of all, the insurer is obliged to pay 1 per cent of the insurance payment as a penalty for each day of delay in the case of unjustified refusal to accept the claim (Law N 40-FZ, art. 12 sec. 21). Moreover, after the Resolution of the Supreme Court of 2012, the relationship between road accident victims and insurance companies started to be treated as a consumer relationship (Resolution N 17 of 28 June 2012). This interpretation means that victims are now protected by the Consumer Rights Act. The provision of this Act prescribes $50 \%$ of the non-paid sum for the benefits of claimants as a fine for unjustified refuse to make payment (Law N 2300-1, art. 13 sec. 5). And finally, victims can claim non-pecuniary damages for consumer rights violation (ibid., art. 15), albeit these are symbolic sums in most cases (normally around 2,000-3,000 roubles). ${ }^{15}$

However, compulsory motor vehicle insurance still does not cover pain and suffering damages. These damages are also not included in compulsory insurance coverage for injuries to military personnel (Law N 52-FZ, para. 2 art. 5) and public transport passengers (Law N 67-FZ, para. 1 art. 16). This exclusion still leaves room for potential legal disputes. Voluntary liability insurance could cover this harm, but it is far from being a popular insurance product in Russia. For example, in the first half of 2003, just before the implementation of compulsory insurance, there were only $5 \%$ of drivers covered by this insurance scheme (Kotlobovsky 2006, p. 32).

The current situation with compensation for workplace accidents and professional deceases is also deeply rooted in the Soviet past. Following the Marxist conception of "withering away" of the state and law, early Soviet legal scholars argued for total substitution of the litigation model with the social "non-fault" insurance scheme in personal injury cases (Hazard 1952). However, these ideas of social insurance model did not succeed in the sphere of employment accidents. The Soviet Civil Code 1922, in which the social insurance model was the most consistent, still left room for claiming compensation through a court procedure. The claim for employment injury damages was allowed if injuries were caused by criminal acts or failure of management to perform duties. Only in these cases, a Soviet citizen had the right to claim compensation above the insurance payment (Art. 413). The injured had the right to make a claim out of social insurance scheme when employment injuries were not covered by social insurance (e.g. in cooperative organisations) or the harm was caused by a third organisation, not the one in which an injured person worked.

The later Civil Code of 1964 moved further away from the social insurance model. It allowed claims for employment injuries if the sum of insurance payment was insufficient. The article 460 of the Code established:

If a worker is crippled or his health is otherwise injured in connection with the performance of his employment (official) duties through the fault of the organization or citizen required to pay premiums for him under state social insurance, such organization or citizen must compensate the injured party for the injury to the extent that it exceeds benefits received by him, or a pension granted to him after the injury to

15 The interview with the insurance lawyer (St Petersburg, 21 August 2019). 
his health and actually received by him. (Civil Code 1964, translated by W. Gray and R. Stults)

These legislative changes represent a significant ideological shift from the early warcommunism to the model of state capitalism (Tay 1969).

The scope of the insurance scheme was relatively broad covering personal injury damages not only caused in a workplace but in other life situations related to work abilities, e.g. accidents on the road to the office or during a business trip. The amount of compensation varied significantly depending on the speciality and level of the worker, membership in a trade union. In fact, claims for extra compensation were relatively rare since most of the victims were satisfied with the minimal insurance payments. The widespread availability of social insurance influenced opinions of Western researchers that "Soviet tort law was conceived mainly as an adjunct to the law of social insurance" (Osakwe 1979).

This social insurance system with the option of litigation remains practically unchangeable in contemporary Russian law. Currently, every employer is obliged to pay monthly premiums to the special state institution which provides social benefits (Social Insurance Fund). In the case of a workplace accident, insurance payments are made regardless of the employer's fault. Though, payments can be reduced up to $25 \%$ if there is gross negligence on the part of the employee. Accident victims have the right to make a claim directly to the Social Insurance Fund. Insurance payments cover lost earnings and other material losses related to personal injuries.

This simplified administrative procedure has substantially reduced legal disputes between employers and employees over accident compensation, albeit could not entirely eliminate them. The issue of pain and suffering damages remains a potential source of disputes. The problem is that social insurance scheme does not provide compensation for non-pecuniary harm (Law N 125-FZ, para. 3 art. 8). The scheme because of this exclusion cannot ensure full protection of the employers' interests (Rogovich 2005, p. 109). There is no compulsory liability insurance which would cover this harm either. As a result, accident victims have to go through court proceedings to obtain relatively moderate compensation for their pain and suffering.

The traditional reluctance of judges to award high compensation for pain and suffering along with the lack of insurance coverage for this harm makes the issue of non-pecuniary damages particularly sensitive in Russia.

\section{Non-pecuniary damages: Current judicial approach and its historical pre- conditions}

There are substantial differences between American and British approaches to nonpecuniary damages. The first unique feature of the US system is the availability of punitive damages in personal injury cases. In contrast to pain and suffering damages which are compensatory by nature, punitive damages are awarded as a punishment "in cases in which the defendant is found to have injured the plaintiff intentionally or maliciously, or in which the defendant's conduct reflected a conscious, reckless, wilful, wanton, or oppressive disregard of the rights or interests of the plaintiff" (Sebok 2009, p. 155). The area where punitive damages (called "exemplary") is possible is more 
limited in England and Wales. There are typical in defamation cases but normally are not available for negligence, no matter how gross it is (Wilcox 2009, pp. 20-21). However, despite the lack of punitive damages for negligence, pain and suffering damages sometimes can perform this function. As Peter Cane suggests, "damages for nonpecuniary loss, and especially damages for bereavement, arguably have a punitive or penal element" (Cane 2018, p. 159).

The second peculiar feature of American personal injury litigation is that the amount of compensation is subject to the jury's discretion, though appeal courts can overturn the verdict if the quantum of awarded pain and suffering damages is clearly unreasonable (Abel 2006, p. 295). As a result, median awards are "enormously larger" (for example, by twenty-five times for quadriplegia) in the US compared to European jurisdictions, including England and Wales (Sugarman 2006, p. 418). The studies comparing jury and judicial decision-making on general damages show that there are noticeable differences in their patterns. Judges tend to assess the risks and consequences of the accident; they are less influenced by cognitive biases than lay jurors (Viscusi 2002). While judges, jurors, and professional lawyers are likely to evaluate the severity of injuries in a similar way, their visions of justice compensation vary significantly (Wissler et al. 1999). The main reason for such differences lies in the fact that juries consider cases occasionally while judges being repetitive decision-makers have a framework of other similar cases. This factor led to the adoption of guidelines for calculating pain and suffering damages in the UK which are based on previous court decisions (Judicial College 2019).

The Russian approach to non-pecuniary damages varies significantly from both countries. These damages ("moral damages") became available in Russia only after the collapse of the Soviet regime. The scope of this remedy was initially very narrow. The statute of 1990 on the regulation of mass media made possible claims for the violation of honour and dignity caused by defamation or libel published or translated in mass media providing non-pecuniary damages as a possible remedy in this cases (Statute of the Soviet Union On Press and other Mass Media, 1990, Art. 39). The list of torts for which non-pecuniary damages can be claimed was widened significantly with the implementation of the Fundamentals of Civil Law in 1991. According to this legislative act, it became possible to claim non-pecuniary damages for any wrongful act which cause physical (personal injuries) or purely moral harm (The Fundamentals of Civil Law of the Soviet Union of 31 May 1991, Art. 131). Importantly, the possible form of remedy was not only money but also other material forms which the court would consider appropriate for covering non-pecuniary harm. This could be, for example, a gift or a ticket to a health resort (Golubev and Narizhniy 2017).

The basic definition of non-pecuniary harm adopted in the Fundamentals has been almost entirely imported to the new Russian Civil Code of 1994 though with two substantive modifications. The ground for claiming non-pecuniary damages has been limited to the non-material harm only (personal injuries, violation of human rights, false imprisonment, libel, etc.). Non-pecuniary damages for material losses became possible only on the condition of a specific statute allowing this remedy. The latter is still exceptional in Russian civil law. The most widely applied and perhaps the only example would be the violation of consumer rights for which a consumer is able to claim pain 
and suffering damages along with or independent of the claim for material losses under the contract (Statute on Consumer Rights Protection, 1992, Art. 15).

The second major change was the exclusion of non-monetary form of compensation which reflects Russia's final transition to a market economy, stabilisation of national currency (rouble) in the middle of 1990s, and commodification of human feelings. Money became the only way to repair non-pecuniary harm as it has always been in Western societies. The current regulation of pain and suffering damages is based on the provisions of the Civil Code which do not contain any further changes in this area since 1994.

The discussion of non-pecuniary damages is better to start with the nomenclature used in Russian civil law. The general term used in the Civil Code for all kinds of nonpecuniary harm caused by wrongful act is "moral damage" (moral'nyj vred) which can be explained by the strong influence of French civil law with its preference of general concept "dommage morale" over specific categories of damages for violation specific rights. The same definition of non-pecuniary damage can be found in other jurisdictions where civil law was built on the Code of Napoleon such as, for example, Belgium or Spain (Banakas 2015). The only definition of "moral damage" which can be identified in the Russian Civil Code is a broad expression "physical and moral suffering" (Civil Code, 1994, Art. 151). The Code does not provide any sub-division of categories of moral damage though some examples can be found in one of the directives of the Supreme Court (Resolution of Plenum of the Supreme Court of 20 December 1994, para. 2) where the following list has been suggested: personal injuries, death of a relative, a disclosure of the family or medical secret, loss of employment, a violation or deprivation of rights, libel and defamation. The list is not exhaustive. The article is focused mostly on the first category from this list.

The assessment of pain and suffering damages, according to the Civil Code, should be based on judicial discretion taking into account the requirements of "reasonableness and justice" (Civil Code 1994, Art. 1101). The final award must reflect the degree of the defendant's fault, the depth of physical and moral suffering, the factual context of causing harm, and individual characteristics of the victim. It does not relate to the quantum of awarded pecuniary damages. The financial situation of the defendant is taken into account and damages can be reduced by court accordingly, excluding cases of intentional harm (ibid., Art. 1083). The claimant's gross contributory negligence is a possible defence which normally results in a reduction of damages. The definition of "gross negligence", however, is not given in the Civil Code which entails problems with differentiation between "gross" and mere contributory negligence in practice. The instruction of the Supreme Court on this issue can barely be helpful for trial courts referring to judicial discretion without further guidance: "each case should be decided after taking into account the actual circumstances of the case (the nature of the activity, the situation of the harm, the individual characteristics of the victim, etc.)" (Resolution of Plenum of the Supreme Court of 26 January 2010, para. 17).

The allocation of the burden of proof in cases on pain and suffering damages is as follows. The claimant is not required to prove the very fact of pain and suffering as it is presumed in personal injury cases since 2010 (ibid., para. 32) in contrast to other categories of cases such as, for example, claims of relatives for wrongful death. The depth 
of pain and suffering, however, still must be proved since it directly relates to the quantum of pain and suffering damages.

The awards for moral damages are relatively low in Russia in comparison to the UK and especially the US. The Judicial Department provides detailed statistics on claims submitted exclusively for pain and suffering damages (o kompensacii moral'nogo vreda $v$ svjazi s prichineniem vreda zhizni i zdorov'ju).

TABLE 2

\begin{tabular}{|l|r|r|r|r|r|}
\hline & Decisions & Satisfied & Partially satisfied & Terminated & Average damages \\
\hline $\mathbf{2 0 1 9}$ & 16,066 & 14,367 & 11,503 & 2,129 & $\mathrm{P} 193,209 / € 2,490$ \\
\hline $\mathbf{2 0 1 8}$ & 17,528 & 15,861 & 11,234 & 2,084 & $\mathrm{P} 170,352 / € 2,200$ \\
\hline $\mathbf{2 0 1 7}$ & 15,995 & 14,450 & 11,762 & 2,171 & $\mathrm{P} 176,619 / € 2,280$ \\
\hline $\mathbf{2 0 1 6}$ & 6,586 & 6,012 & 4,702 & 996 & $\mathrm{P} 169,821 / € 2,190$ \\
\hline
\end{tabular}

Table 2. Court decisions on non-pecuniary damages caused by personal injury and fatal accidents in 20162019.

As Russian judicial statistics demonstrate, there were 16,066 decisions on pain and suffering damages in 2019; among them, 14,367 decisions were in favour of claimants. However, 11,503 claims were satisfied only partially which means that courts did not award damages in the amounts claimants had claimed in these cases. The total sum of the damages awarded in 2019 comprises P2,775,847,565 what gives us an average compensation (arithmetic mean) in the amount of $\$ 193,209$ (about $€ 2,490$ ). It needs to be mentioned that the official statistics do not allow calculating the median sums. Therefore, one can concede the effect of atypical high compensations, in particular, cases while in the majority the awarded sums would be relatively moderate. There is a dramatic (almost doubly) rise of moral damages claims and cases between 2016 and 2017 which is seen in official statistics. The most probable explanation of these changes is an economic recession and currency fall happened in this period because of the drop in oil prices and economic sanctions. The insurance coverage limits might not reflect the changing economic reality, so more claimants were prepared to seek general damages than previously. However, a more prosaic reason can lie in the changed approach collecting statistical data, albeit there is no indication of this among the instructions and documents of the Russian Judicial Department.

The analysis of claims for non-pecuniary damages filed in Russian courts in 2016-2019 indicates that there is a significant gap between what claimants expect from the judicial system and how the judicial system responds to these expectations. For example, the average quantum of claimed damages (razmer zajavlennyh iskovyh trebovanij) was $\mathbf{P} 1,261,514(€ 16,290)$ in 2019 which is substantially higher than the average nonpecuniary damages awarded by Russian courts (see Table 2 above). This gap demonstrates that there is a difference between claimants' and judges' perceptions of the justified and reasonable quantum of moral damages. The distribution of cases by the claimed damages also illustrates this gap. The largest category includes sums P100KP300K (€1,290-€3,870) which is close to the average award ("realistic" approach), however, the second large category includes the highest sums that is more than $\mathrm{P} 1 \mathrm{~m}$ $(€ 12,900)$ which is very unlikely to be fully satisfied ("idealistic" approach) but claimants keep seeking them. 
TABLE 3

\begin{tabular}{|r|r|r|r|r|r|r|}
\hline & $<$ P50K & $\begin{array}{c}\text { P50K- } \\
\text { P100K }\end{array}$ & $\begin{array}{c}\text { P100K- } \\
\text { P300K }\end{array}$ & $\begin{array}{c}\text { P300K- } \\
\text { P500K }\end{array}$ & P500K-P1m & $>$ P1m \\
\hline $\mathbf{2 0 1 9}$ & 1,585 & 1,583 & 3,387 & 1,426 & 2,147 & 2,929 \\
\hline $\mathbf{2 0 1 8}$ & 2,350 & 2,128 & 3,436 & 1,335 & 1,920 & 2,671 \\
\hline $\mathbf{2 0 1 7}$ & 1,951 & 1,514 & 3,147 & 1,192 & 1,917 & 2,689 \\
\hline $\mathbf{2 0 1 6}$ & 648 & 656 & 1,254 & 465 & 709 & 904 \\
\hline
\end{tabular}

Table 3. The quantum of claimed moral damages in personal injury and fatal accident cases in 2016-2019.

One of the possible explanations for this is that the judiciary takes into account the lack of insurance covering moral damages and the financial position of the defendant which would be irrelevant not in common law jurisdictions but also in European civil law jurisdictions. The most typical factors which courts take into account are the amount of the defendant's salary, the number of dependents, available assets and the level of credit debts.

The arguments of the appeal that the first instance court unreasonably reduced the amount of compensation for non-pecuniary damage, taking into account the difficult financial situation of the defendant, the panel of judges dismisses as unfounded. This conclusion of the first instance court was based on the evidence submitted and examined by the court, namely, personal income tax certificate, a copy of the loan agreement, birth certificates of children, certificates of debt on loans, which were evaluated in accordance with the Art. 67 of the Civil Procedure Code of the Russian Federation. (Case n⿳⺈ 33-3400/2017)

The other problem with moral damages in Russia is the inconsistency of awards which are not determined by judicial practice even on the level of the same region. The reason which can be frequently met in court decisions is that Russia is not a common law jurisdiction and precedents are not binding in any way.

The defendant's reference to judicial practice in deciding on the amount of compensation for moral damage is found insolvent by the judicial board, since the amount of compensation in each case is determined individually, based on the particular case, and cannot be made dependent on the amount of such compensation determined by other courts resolving other matters. Moreover, judicial precedent is not a source of law in the Russian Federation. (Case nº 33-16487/2017)

This rationale with reference to the continental legal system, however, is not persuasive since in many European jurisdictions the tendency to standardisation in awarding general damages is strong. The avoidance by the Russian judiciary to follow previous decisions in regards to damages seems exceptional even for a civil law jurisdiction. For example, in Germany, there are tables of typical Schmerzensgeld awards (pain and suffering damages) based on the systematised judicial practice and collected by private organisations (Fedtke 2012). Although these tables are not binding, and German courts enjoy relatively wide discretion, it is still a conventional practice to motivate decisions by the reference to the mentioned tables. Similar tables or guidelines can be found in the Netherlands, Belgium, Austria, and Italy (Karapanou and Visscher 2010).

The lack of standardisation in awarding general damages makes pre-trial settlements problematic since the views of the defendant and claimant on the reasonable quantum of damages could differ dramatically. This complicates significantly the work of 
practising lawyers who cannot predict the outcome of the case and consult their clients accordingly.

Indeed, today it is impossible even to make a preliminary forecast of how much compensation can be received. It's like a roulette game. Only when I submit a claim and see which judge got it, what cases considered before and what judgments made, then I start to roughly understand what to expect. Everything comes down to the human factor. (Anastasia Kopteeva, quoted in Lenta 2019)

A detailed explanation of reasons for awarding a particular sum of money can be rarely found in court practice. In most cases, a brief reference to the principle of "reasonableness and fairness" is considered to be a sufficient justification of the awarded damages.

However, despite all the negative consequences of the current judicial approach, there is a strong reluctance towards any changes in this sphere. The most probable explanation for this reluctance is the legacy of the Soviet approach to moral damages. As one of the Supreme Court judges recently described the general attitudes of Russian judiciary, "a usual picture is meagre compensation for moral harm because there has always been a view that moral damages cannot be determined financially". ${ }^{16}$ These Soviet cultural attitudes seem to be stronger among senior judges. The interview with a former Moscow district judge where he discussed one of the railroad accident cases vividly illustrates this point.

I awarded 800,000 roubles as pain and suffering damages. And after the appeal of Russian Railways, in such circumstances, with a demolished head, they [appeal judges] reduced it to 80,000 (...). In the case of Russian Railways, I believe that this is the practice of caring for the budget. In other cases, these are traditional moral positions of our judges, mostly from the past, who are still working, who act as they pour out this money from their own pockets. ${ }^{17}$

The survey of judges conducted in February 2020 demonstrates that their median estimations of just compensation are much higher than actual awards (Association of Russian Lawyers and Financial University of the Government of the Russian Federation 2020). The sample included 118 practising federal judges from different age groups and with varying length of service. The median awards of pain and suffering damages fluctuate between 70,000 roubles $(€ 900)$ and $2 \mathrm{~m}$ roubles $(€ 25,800)$ depending on the severity of injuries and circumstances of the accidents. Importantly, the estimations vary significantly across age cohorts of the respondents. The highest awards were suggested by young judges aged 25 to 40 years with the work experience of lesser than 5 years. In contrast, senior judges started their career in the Soviet times tend to suggest lower figures.

Therefore, a brief overview of the historical roots of this approach to pain and suffering damages in Russia would be particularly productive. Since the establishment of the Soviet regime in 1917, there was a strong backlash against the idea of moral damages among legal scholars and judges. At first sight, it seems to be in continuity to the prerevolutionary doctrinal approach of prohibiting moral damages (Gray 1964). Indeed, in the Tsarist period, there was a strong reluctance towards non-pecuniary damages. The

\footnotetext{
16 The Supreme Court judge conceives that the quantum of moral damages should be higher; see TASS 2018.

17 The interview with Sergey Savostyanov (a former district judge), in Kozkina 2019.
} 
very idea of compensation for suffering seemed to be an inherent contradiction for some lawyers. If a person suffers real moral harm, it could not be covered by any money; if it could be, it is not "real" harm (Shershenevich 1911). It was considered appropriate to seek this remedy only by the members of lower classes without any sense of honour (Erdelevskiy 2013). There were strong class presuppositions which were responsible for mostly negative views on moral damages since most lawyers were from a privileged noble group (dvorynstvo) or upper-middle class. The same attitudes can be observed among English lawyers in the $19^{\text {th }}$ century ${ }^{18}$ or the authors of the German Civil Code. ${ }^{19}$

However, the rhetoric shaping the ban on moral damages changed dramatically from the issues of honour and dignity to the issue of "commodification". For example, in 1923, the Kharkiv regional appeal court reversed the decision of the district court on awarding moral damages (Zeits 1927). The appellate judgment explained that in the case of personal injury the task of civil law is to return person into the previous state, i.e. recover her working abilities. That is why only the lost salary could be compensated but not general damages. As Soviet legal scholars saw it, civil law in socialist society could have only secondary functions in relation to the development of economic productivity. As soon as compensation of moral damages does not provide economic benefits, the protection of personality should be exclusively in the sphere of criminal law (ibid.). The other problem which irritated the Soviet legal mind was unavoidable judicial discretion in awarding compensation. That would contradict the basic principle of the statutes' priority in the socialist law system (Kantorovich 1928). If in the first decade of the Soviet regime a discussion on moral damages still existed, from the 1930s this remedy started to be identified entirely with the capitalist legal thought. As Soviet legal scholars argued, pain and suffering could not be turned into the monetary form ("commodified") in a socialist society.

In contrast, bourgeois law - especially English law, imbued with the spirit of commercialism - permits monetary valuation of the so-called 'moral harm'. From the point of view of the bourgeoisie, only that which has exchange value, market value, is valuable. (Novitsky and Luntz 1950: § 49)

There was a solid ideological basis underpinning the prohibition of non-pecuniary damages in Soviet law. This linked to the anti-commodification attitudes which tort law tried to develop in common Soviet citizens (Osakwe 1979). However, all the examples on general damages proposed by the Soviet scholars were non-typical, like adultery or death of a beloved dog (Fleishits 1951) rather than a large number of personal injuries inevitably increasing with the industrialisation. The reason for attributing lesser

\footnotetext{
${ }^{18} \mathrm{cf}$. "A jury most certainly has a right to give compensation for bodily suffering, unintentionally inflicted. But when I was at the bar, I never made a claim in respect of it, for I look on it, not so much as a means of compensating the injured person, as of damaging the opposite party. In my personal judgment, it is an unmanly thing to make such a claim. Such injuries are part of the ills of life, of which every man ought to take his share". Chief Baron Pollock in Theobald v. Railway Passengers' Assur. Co., 26 Eng. L. and Eq. R. 438 (1854) cited in O'Connell and Carpenter 1983, p. 12.

$19 \mathrm{cf}$. "There is, for one, a traditional German reluctance to provide compensation for non-pecuniary loss which dates back to the original drafters of the BGB and is still the starting point of the Code today. It was considered highly questionable, at least in the more influential 'upper classes' of society, to claim such compensation due to the perceived moral hazard inherent in human nature; monetary gain, self interest, and greed had to be kept at bay - according to the prevailing sentiment at the time - by limiting nonpecuniary loss to a few exceptions specifically determined by the legislator" (Fedtke 2012, p. 199).
} 
importance to personal injuries could lie in the fact that all Soviet organisations and institutions (repetitive defendants) were public so it meant that moral damages would be paid by public money.

The concerns of the State about the excessive damages which would be paid out from public funds presumably led to the participation of the procurator in personal injury cases. This rule still exists in modern Russian civil procedure, and procurators participate in most personal injury cases and provide their conclusion on liability and quantum issues as a third party (Russian Civil Procedural Code, Art. 45). They can also participate in personal injury cases on behalf of the claimants who cannot allow legal representation. Non-participation of the procurator in a personal injury case can serve as an additional argument for overruling the first instance court judgment.

In addition, noteworthy are the arguments of the cassation appeal of the defendant that the prosecutor was not involved in the case, while by virtue of Part 3 of Art. 45 Code of Civil Procedure of the Russian Federation, his participation is mandatory in cases of compensation for harm caused to life or health. ${ }^{20}$

This is an evident rudiment of Soviet tort system where the majority of tort cases included the interests of the State which required the involvement of procurator.

However, since the 1960s (after the Khrushchev Thaw) the situation with moral damages started to change. Soviet legal academics and practitioners arrived at a consensus on the necessity for non-material damages as a means of human rights protection and punishing a tortfeasor (Barry 1979). The proponents for reform referred to the experience of Eastern European countries in which moral damages were recognised despite their socialist legal systems. In most of these countries, there was a ban on moral damages established by legislation or Supreme Court resolutions after communists took the power. However, these restrictive principles were formulated in rather flexible terms so lower courts started to bypass this ban in their day-to-day practice liberally interpreting the rules. ${ }^{21}$ This was a general trend in Eastern European countries after the 1960s when courts began to interpret "against the grain" ideologically based general clauses directed from above, not only in respect to moral damages (Ajani 2002). However, the restrictive approach towards moral damages, despite the strong request from the lawyers, remained unchanged in the Soviet Union.

Only in the period of Perestroika, general damages ("moral damages") were implemented for the first time. The Law of the Press 1990 involved the remedy for nonpecuniary damages caused by the act of defamation in mass media ("claim in defence of honour and dignity"). From the beginning, the lack of accurate criteria caused difficulties for judges in the determination of the amount of compensation. The awarded sums were relatively moderate compared with Western countries in the 1990s. The situation did not change significantly with the implementation of the general norm on moral damages into the new Civil Code of 1994. It appears that the current approach keeps the continuity with the Soviet position towards awarding general damages. It is noteworthy in this connection that the current tort law in China, one of the few remaining socialist

\footnotetext{
20 See, for example, Cassation Judgment no 361 of 5 July 2017, Moscow Region Cassation Court.

${ }^{21}$ See more details on moral damages in socialist Hungaria in Solyom (1981); on Poland, in Szpunar (1967); on Bulgaria, Romania, and Czechoslovakia, in Smith (1980).
} 
countries, still hardy recognises non-pecuniary damages and allows them only in exceptional circumstances when serious emotional damage was caused (Koziol and Zhu 2010).

\section{The legal profession and personal injury litigation}

The problem of "compensation culture", in the UK or US is closely related to the activity of personal injury lawyers and claim handlers taking cases on the conditional fee basis. Specialisation in personal injuries become well-established in the UK and the US involving not only professional lawyers but also a substantial number of non-qualified assessors working for claim management companies. The readiness of legal practitioners to initiate legal procedure causes a notion of moral hazard (Santore and Viard 2001). However, there are opposite views on the role of lawyers in litigation rate. In this perspective, the participation of lawyers at early stages of dispute prevents its transformation into the litigation form. Professional representatives tend to evaluate risks more accurately and would prefer settlement instead of costly litigation (Korobkin and Guthrie 1997). The studies of compensation culture concentrate mainly on the readiness of claimants and lawyers to seek compensation for personal injuries, i.e. on the pre-trial stages. The socio-legal model of litigation divides this preliminary stage into three parts: naming, blaming, and claiming. At the stage of naming, a victim must recognise a tortuous act as a violation of his/her rights; at the stage blaming s/he defines who is responsible for the wrongdoing; only at the stage of claiming these feelings shape into the proper legal form (Felstiner et al. 1980-81). In fact, the majority of potential claims do not overcome the first and second stages. The role of legal professionals is crucial for the evolution of ordinary people's motives. It is a lawyer who makes the assessment of risks and encourages or discourages claimants to litigate. In this respect, the increasing number of law firms and barrister chambers specialising in personal injury litigation is the key factor of the long-term increase in the number of claims as well as amounts of compensation. The availability of "no win, no fee" agreements is one of the institutional factors which affects claiming behaviour (Kritzer 2011).

There are substantial differences between the legal professions in the US and UK. The most obvious difference is that American lawyers are united into one professional corporation whereas British legal profession is divided into solicitors and barristers (or advocates in Scotland). However, what is most important is that means of legal funding and development of specialisation in personal injury cases are similar in both countries. The allowance of conditional fee agreements and also contingent fees (since "Jackson reforms") $)^{22}$ made the personal injury specialisation more attractive and profitable for legal firms. In the UK, they organised in 1990 a professional association called the Association of Personal Injury Lawyers (APIL). ${ }^{23}$ A similar trend to specialisation in personal injuries can be observed in the US ${ }^{24}$ and some European countries. ${ }^{25}$ There is a

\footnotetext{
${ }^{22}$ The recommendations of the Lord Justice Jackson's report were implemented by Legal Aid, Sentencing and Punishment of Offenders Act (LAPSO) of 1 April 2013.

${ }^{23}$ See more details on APIL official website: https://www.apil.org.uk/ (accessed on 23 June 2020).

24 E.g. American Association for Justice (formerly known as National Association of Claimants' Compensation Attorneys, NACCA) website: https://www.justice.org/ (accessed on 23 June 2020).

25 E.g. Association Nationale des Avocats de Victimes de Dommages Corporels in France. Website: http://anadavi.org/ (accessed on 23 June 2020).
} 
link between lawyers' activity and quantum of general damages since part of the latter is supposed to cover conditional or contingency fees which could result in growing "commodification" of damages, i.e. moving far from the title function of reimbursing pain and suffering to a pure financial rationale behind them (Abel 2006). Personal injury lawyers start to believe that in most cases the true driver for claiming compensation is the wish to gain a considerable sum of money even for minor injuries (Ilan 2011). Therefore the neoliberal logic of commodification is reproduced on a daily basis by claimants and professional legal representatives in personal injury cases.

If we look at the Russian context, we would not find the same impact of the legal profession on personal injury litigation. There is no requirement of professional legal representation in personal injury jury cases at any level of the Russian court system. The parties can participate in litigation personally or through legal representation depending on their preference and financial capacity. The only requirement for legal representatives is a law degree in appeal and cassation proceedings. This relaxed regime makes the market of legal services in civil cases extremely saturated. There are solo practitioners, qualified and non-qualified, and law firms offering their services in the various categories of civil cases. And yet, specialisation in personal injury cases is not well established. There is no professional association of personal injury lawyers analogous to those which currently operate in the US or UK. There is though a broader specialisation in road traffic accidents but rather in car damages than in personal injuries.

The most likely reason for the lack of specialisation is the low level of general damages and legal costs paid by the losing party. As a result, there is little financial interest in taking these cases for lawyers.

TABLE 4

\begin{tabular}{|l|r|r|r|}
\hline & RTA & \multicolumn{1}{|c|}{ Work } & \multicolumn{1}{c|}{ Other } \\
\hline $\mathbf{2 0 1 9}$ & $\mathrm{P} 3,152 / € 41$ & $\mathrm{P} 3,738 / € 48$ & $\mathrm{P} 2,691 / € 35$ \\
\hline $\mathbf{2 0 1 8}$ & $\mathrm{P} 3,961 / € 51$ & $\mathrm{P} 5,092 / € 66$ & $\mathrm{P} 2,944 / € 38$ \\
\hline $\mathbf{2 0 1 7}$ & $\mathrm{P} 2,833 / € 36$ & P4,376/€56 & Р4,386/€57 \\
\hline
\end{tabular}

Table 4. Legal costs in personal injury and fatal accident cases in 2017-2019.

It is clear from this data on mean legal costs (sudebnye izderzhki) per case that they are much lower in Russia than in the UK where legal costs can reach sometimes the level of claimed damages. ${ }^{26}$ According to the Civil Justice Review, the average legal costs in the High Court are $50-75 \%$ of the awarded damages while in the county courts the proportion is much higher reaching $125-175 \%$ of the awarded damages (Civil Justice Review, cited in Cane 2018, p. 378).

The other impediment to the development of personal injury specialisation is the restricted approach to conditional and contingent fees in Russia. This form of legal funding is not formally banned but remains in the "grey zone". The Code of Professional Ethics allows for the possibility of concluding such agreements in all cases, except criminal cases (Code of Professional Ethics of Advocates of 31 January 2003, sec. 3 art. 16). However, the two highest Russian courts took the opposite position to the code on

\footnotetext{
${ }^{26}$ E.g. "One of my cases this week where damages are about eight hundred thousand pounds, and costs exceed six hundred thousand pounds because we got experts, we need a video-link from Australia and it's a hugely costed process anyway" (PI solicitor, London, 14 November 2018).
} 
this issue. Lawyers can enter into agreements with such conditions, but they do not receive judicial protection. In disputes with customers, money under these agreements cannot be recovered, since the condition of "success fee" is recognized as null and void. The justification for such a position is a corruption risk (the lawyer may try to illegally influence the positive outcome of the case), as well as the exorbitant burden of expenses to reimburse the "success fee", which will ultimately fall on the losing side.

Therefore, litigation in person is more common in personal injury cases than in the UK or US, ${ }^{27}$ even in the case of grave injuries. Russian lawyers try to push forwards some measures in order to resolve the problem of low moral damages. These attempts are supported by the Federal Association of Advocates and Association of Russian Lawyers as the most institutionalised organisations of legal professionals in Russia. The first suggestion is to try to change the attitudes of Russian judges, and the second is to implement tariffs or standards with mandatory minimal awards of moral damages. In arguing for changes in this sphere they try to call not only moral logic but also economic which is apparently more significant for the government. These initiatives received some feedback from Russian highest judiciary admitting that the current level of moral damages is insufficient but without any practical steps for changing the judicial approach.

\section{Conclusion}

The analysis of personal injury litigation in Russia shows that there are no reasons to talk about litigiousness in the sphere of compensation for personal injuries. The number of personal injury cases per population is not high, and there is an evident trend of its decrease. This can be explained by the development of compulsory insurance like in the UK or US where the disputes over personal injury compensation moved from the courts to insurance companies. However, the distinctive feature of the Russian tort system is that claimants still have to sue defendants directly if they seek damages above the insurance limits (relatively low) and non-pecuniary damages. Taking this into account, the intensity of personal injury litigation is surprisingly low. The claimants have formal rights to make a claim in every accident for pain and suffering damages where there is someone's fault but they do not seem to be too ready to do this.

These claiming patterns can be explained by the continuity of the Soviet litigation patterns. The avoidance of court disputes was a well-known trend in the socialist Eastern European countries where the citizens were not prepared to make claims against the State institutions which were the typical defendants in most cases (Markovits 1989). The scepticism toward official legal institutions is still evident in Russia where people's trust in the judicial system is extremely low, according to national surveys. ${ }^{28}$ This lack of trust in courts does not contradict the general increase in the use of courts by Russians since in most cases individuals and companies have to submit a claim to achieve a necessary legal result (Hendley 2012). For example, a court judgment is frequently needed to

\footnotetext{
27 The research by Centre for Socio-Legal Studies (Oxford) demonstrated that only 8\% of personal injury cases are settled without legal representation in the UK. See in Harris et al. 1984, p. 81.

${ }^{28}$ According to the survey conducted by the Fund of Public Opinion (FOM) in 2018, only $24 \%$ of respondents assessed the work of Russian judicial system positively, and only 31\% of them were prepared to bring their claim to the court while 57\% treated it as a last resort. See FOM 2018.
} 
confirm property rights, to obtain a divorce or get payments under a contract. There is no real dispute behind these cases. However, personal injury cases differ from this general trend since a victim is free to choose between making a claim or "lump" it. If we look at the Anglo-Saxon context, the awareness of people of their rights has changed significantly which has resulted in a greater willingness to make a personal injury claim (Lewis 2014). That is not the case in Russia. For example, Hendley shows drawing on focus groups and interviews that road accident victims are reluctant to submit a claim to the court even if they are entitled to compensation (Hendley 2017). The statistics of personal injury cases discussed above support this finding.

The more pragmatic explanation is the low level of non-pecuniary damages. If we look at the Russian statistics, the average quantum of damages in all type of cases would barely reach the average in the most trivial types of claims in the UK or US. Meanwhile, it is evident from the statistics that there is a clear demand from claimants and lawyers for a more generous approach of Russian judiciary. The gap between the claimed and awarded moral damages, according to the statistics, is critical. The level of awards and ban of contingent fees does not attract Russian lawyers to take these cases and prevents specialisation in personal injuries in the Russian legal market where non-qualified practitioners still prevail. This, in turn, apparently results in remaining low level of moral damages in Russia since there is no need to cover conditional fees, and litigants in person would normally participate in the majority of cases. The other specificity is the lack of consistency in awards of moral damages in Russia which makes it hard to settle cases. Indeed, the proportion of settled or mediated cases is much lower in Russia than in the US or UK where only the minimum of personal injury reaches the trial stage.

The lack of compulsory insurance covering moral damages is another distinctive feature of Russian tort system which cannot be found in the UK or US where insurance would normally cover pain and suffering damages. The comparison above raises a variety of questions about the preconditions of the tort systems in Russia and England. The basic question is why Russian judges are so reluctant to award higher general damages. The historical background can shed some light on this situation. There were strong grounds of a class nature against general damages in the pre-revolutionary Russian as well as in the Soviet era. However, these grounds were of a different kind. In the first case, claiming moral damages was treated as a dishonourable model of behaviour which is acceptable only to the most deprived social groups. The same upper-class reasoning could be met in the statements of English legal scholars and practitioners of that period. Later, the two cultures took different paths. The industrialisation and associated accidents opened the door for general damages in England while in Soviet Russia there were completely prohibited as an inappropriate commodification of human feelings. The senior members of Russian judiciary, especially in the appeal courts which are supposed to control the practice of awarding damages, are mostly from the Soviet generation so the views and attitudes from that time can be still strong amongst them (Hendley 2007).

The further issue concerns the consistency in awards, i.e. why the idea of standardising awards of general damages is not welcome in Russia, in contrast to the English situation. The implementation of JCG and abolition of juries seem to be the logical reaction of the English tort system to the demands of insurance business and legal profession needed 
some reference points in order to settle cases. ${ }^{29}$ The lack of any standards distinguishes Russia not only from England but from any other, relatively similar, civil law jurisdictions (German or French). The official rhetoric of the Russian judiciary frequently met in the judgments stresses the non-precedent character of the Russian legal system. However, the lack of interest of the Supreme Court and appellate courts in setting standards can be also explained from a more pragmatic perspective. In the absence of insurance business involved and settlements, there are no practical reasons to limit judicial discretion.

Final, and probably the most complicated question, is why compulsory liability insurance was implemented so lately (in 2003) and still does not cover general damages. The peculiarity of the Soviet tort system was the emphasis on the deterrence function of liability contrary to the expected shift to the completely non-fault compensation scheme (Darby 1984). There was a strong position in favour of personal responsibility, similar to the views on the moral and legal inappropriateness of liability insurance in Anglo-Saxon societies in the $19^{\text {th }}$ century. However, again, with industrialisation, compulsory liability insurance became the basis for Western tort law which is still not widely accepted in Russia despite the deplorable situation with the enforcement of judgements in civil matters. ${ }^{30}$ The obligation of Russian courts to consider the degree of fault and financial position of the defendant, which is totally alien to common law jurisdictions, is another evidence of the survived Soviet approach with its priority of deterrence over the compensatory function of damages. To summarise, in regards to personal injury litigation Russia despite the evident economic and social prerequisites for change in a similar direction to the UK or US (legal market, insurance business, a substantial number of accidents, and public demand for higher general damages) there are solid cultural grounds, inherited from the Soviet past, which does not allow these changes to materialise entirely.

\section{References}

Abel, R., 2006. General damages are incoherent, incalculable, incommensurable, and inegalitarian (but otherwise a great idea). DePaul Law Review [online], 55(2), 253. Available from: https://via.library.depaul.edu/law-review/vol55/iss2/3/ [Accessed 1 July 2020].

Ajani, G., 2002. Formalism and anti-formalism under socialist law: The case of general clauses within the codification of civil law. Global Jurist Advances [online], 2(2). Available from: https://doi.org/10.2202/1535-1661.1074 [Accessed 1 July 2020].

Association of Russian Lawyers and Financial University of the Government of the Russian Federation, 2020. Analiticheskij Otchet po rezul'tatam Issledovanija ocenki sud'jami RF razmera spravedlivoj kompensacii moral'nogo vreda pri prichinenii vreda

\footnotetext{
29 "Consistency is important because it assists in achieving justice between one claimant and another and one defendant and another. It also assists to achieve justice by facilitating settlements. The courts have become increasingly aware that this is in the interest of litigants and society as a whole" (Lord Diplock on the role of JCG in Heil v Rankin [2000] EWCA Civ 84 [25] cited in Dingwall and Cloatre 2006).

${ }^{30}$ For example, according the official statistics of the Russia's Federal Bailiffs Service, in the cases where the defendant and claimant were both individuals (typical for RTA), only $23 \%$ of judgments were fully enforced in 2018 (see http://fssp.gov.ru/statistics/, accessed 23 June 2020).
} 
zhizni ili zdorov'ju [Analytical Report by the Results of the Study of Russian Judges' Estimations of Fair Compensation for Pain and Suffering in Personal Injury and Fatal Accident Cases] [online]. Available from: https://zakon.ru/Tools/DownloadFileRecord/24384 [Accessed 23 June 2020].

Atiyah, P.S., 1987. Tort law and the alternatives: Some Anglo-American comparisons. Duke Law Journal [online], $\mathrm{n}$ ㅇ 6, 1002. Available from: https://doi.org/10.2307/1372595 [Accessed 1 July 2020].

Baker, T., 2001. Blood money, new money, and the moral economy of tort law in action. Law \& Society Review [online], 35(2), 275-319. Available from: https://doi.org/10.2307/3185404 [Accessed 1 July 2020].

Banakas, S., 2015. Non-Pecuniary Loss in Personal Injury: Topography Architecture and Nomenclature in the European Landscape. Journal of Comparative Law [online], 10(2), 291. Available from: https://core.ac.uk/reader/41993142 [Accessed 1 July 2020].

Barry, D.D., 1979. Soviet Tort Law and the Development of Public Policy. Review of Socialist Law [online], 5(1), 229. Available from: https://doi.org/10.1163/157303579X00172 [Accessed 1 July 2020].

Blankenburg, E., 1997. Civil Litigation Rates as Indicators for Legal Culture. In: D. Nelken, ed., Comparing Legal Cultures. London: Routledge, 41-68.

Brüggemeier, G., 2011. European civil liability law outside Europe. The example of the big three: China, Brazil, Russia. Journal of European Tort Law [online], 2(1), 1-22. Available from: https://doi.org/10.1515/jetl.2011.1 [Accessed 1 July 2020].

Bussani, M., and Infantino, M., 2015. Tort Law and Legal Cultures. The American Journal of Comparative Law [online], 63(1), 77-108. Available from: https://doi.org/10.5131/AJCL.2015.0003 [Accessed 1 July 2020].

Cane, P., 2018. Atiyah's Accidents, Compensation and the Law. Cambridge University Press.

Cotti, A., et al., 2004. Road traffic accidents and secondary victimisation: the role of law professionals. Medicine and Law [online], 23(2), 259. Available from: https://pubmed.ncbi.nlm.nih.gov/15270469/[Accessed 1 July 2020].

Darby, J.J., 1984. The Influence of Marxian Socialism on the Soviet Law of Torts. Columbia Journal of Transnational Law, 23, 373.

Davydenko, D., 2013. Mediation in Russia: Regulation and Practice. In: K.J. Hopt and F. Steffek, eds., Mediation: Principles and Regulation in Comparative Perspective. Oxford University Press.

Dingwall, R., and Cloatre, E., 2006. Vanishing trials: an English perspective. Journal of Dispute Resolution [online], $\mathrm{n}^{\mathrm{o}}$ 1, 51. Available from: https://scholarship.law.missouri.edu/jdr/vol2006/iss1/7 [Accessed 1 July 2020].

Engel, D.M., 2016. The Myth of the Litigious Society: Why We Don't Sue. University of Chicago Press. 
Erdelevskiy, A., 2013. Kompensacija moral'nogo Vreda [Compensation of moral damage] (online). Consultant Plus legal database. Available from: http://www.consultant.ru [Accessed 6 July 2020].

Fedtke, J., 2012. The Culture of German Tort Law. Journal of European Tort Law [online], 3(2), 183. Available from: https://doi.org/10.1515/jetl-2012-0183 [Accessed 1 July 2020].

Felstiner, W.L., Abel, R.L., and Sarat, A., 1980-1981. The Emergence and Transformation of Disputes: Naming, Blaming, Claiming... Law \& Society Review [online], 15(3-4), 631-654. Available from: https://doi.org/10.2307/3053505 [Accessed 1 July 2020].

Fleishits, E.A., 1951. Obyazatelstva iz Prichinenia Vreda i iz Neosnovatelnovo Obogashchenia. [Obligations for Causing Injury and for Unjust Enrichment]. Moscow:

Gosyurizdat.

Fogelson, Y., 2012. Strahovoe pravo: teoreticheskie osnovy i praktika primenenija [Insurance Law: Theoretical Grounds and Practice of Applying]. Moscow: Norma.

FOM, 2018. Sudy: predostavlenija ob ih spravedlivosti, nezavisimosti, lichnyj opyt. (Report). FOM [online], 5 August. Available from: https://fom.ru/Bezopasnost-ipravo/14080 [Accessed 23 June 2020].

Galanter, M., 1974. Why the "haves" come out ahead: Speculations on the limits of legal change. Law \& Society Review [online], 9(1), 95-160. Available from: https://doi.org/10.2307/3053023 [Accessed 1 July 2020].

Golubev, K., and Narizhniy, S., 2017. Kompensatsiya Moral'nogo Vreda Kak Sposob Zashchity Neimushchestvennykh Blag [Compensation for Moral Harm as a Way of Protecting Immaterial Interests]. Legal Centre Press.

Gray, W., 1964. Soviet Tort Law: The New Principles Annotated. University of Illinois Law Forum [online], 180. Available from: https://repository.law.umich.edu/articles/751 [Accessed 1 July 2020].

Harris, D., et al., 1984. Compensation and Support of Illness and Injury. Oxford University Press.

Hazard, J.N., 1952. Personal Injury and Soviet Socialism. Harvard Law Review [online], 65(4), 545. Available from: https://doi.org/10.2307/1336761 [Accessed 1 July 2020].

Hendley, K., 2007. Are Russian Judges Still Soviet? Post-Soviet Affairs [online], 23(3), 240-274. Available from: https://doi.org/10.2747/1060-586X.23.3.240 [Accessed 1 July 2020].

Hendley, K., 2012. The puzzling non-consequences of societal distrust of courts: explaining the use of Russian courts. Cornell International Law Journal [online], 45, p. 517. Accessed from: http://scholarship.law.cornell.edu/cilj/vol45/iss3/1 [Accessed 6 July 2020].

Hendley, K., 2014. Judges as gatekeepers to mediation: The Russian case. Cardozo Journal of Conflict Resolution [online], vol. 16, 423. Available from: 
https://media.law.wisc.edu/m/fdd3z/hendley judges as gatekeepers.pdf [Accessed 1 July 2020].

Hendley, K., 2017. Everyday Law in Russia. Cornell University Press.

Ilan, J., 2011. The commodification of compensation? Personal injuries claims in an age of consumption. Social \& Legal Studies [online], 20(1), 39-55. Available from: https://doi.org/10.1177/0964663910379490 [Accessed 1 July 2020].

Judicial College, 2019. Guidelines for the Assessment of General Damages in Personal Injury Cases. $15^{\text {th }}$ edition. Oxford University Press.

Kantorovich, Y.A., 1928. Osnovnye idei grazhdanskogo prava. [The main ideas of civil law]. Kharkov: NKYu USSR.

Karapanou, V. and Visscher, L., 2010. Towards a better assessment of pain and suffering damages. Journal of European Tort Law [online], 1(1), 48-74. Available from: https://repub.eur.nl/pub/31474/jetl.2010.48.pdf [Accessed 6 July 2020]

Khudyakov, A., 2010. Teorija strahovanija [The theory of insurance]. Moscow: Statut.

Korobkin, R., and Guthrie, C., 1997. Psychology, economics, and settlement: A new look at the role of the lawyer. Texas Law Review, 76, 77.

Kotlobovsky, I., 2006. The Prospects for Motor Insurance in Russia. Journal of Risk Management and Insurance [online], 11(1). Available from: https://jrmi.au.edu/index.php/jrmi/article/view/85 [Accessed 1 July 2020].

Koziol, H., and Zhu, Y., 2010. Background and key contents of the new Chinese Tort Liability Law. Journal of European Tort Law [online], 1(3), 328-361. Available from: https://doi.org/10.1515/JETL.2010.328 [Accessed 1 July 2020].

Kozkina, A., 2019. “Lichno mne v soveshhatel'nuju komnatu Ol'ga Egorova ne zvonila". Byvshij sud'ja (i izbrannyj deputat Mosgordumy) Sergej Savost'janov o sebe i o sisteme, iz kotoroj on ushel. Mediazona [online], 9 September. Available from: https://zona.media/article/2019/09/09/savostianov [Accessed 23 June 2020].

Kritzer, H.M., 1991. Propensity to sue in England and the United States of America: blaming and claiming in tort cases. Journal of Law and Society [online], 18(4), 400427. Available from: https://doi.org/10.2307/1410316 [Accessed 1 July 2020].

Kritzer, H.M., 2004. Disappearing trials? A comparative perspective. Journal of Empirical Legal Studies [online], 1(3), 735-754. Available from: https://doi.org/10.1111/j.17401461.2004.00022.x [Accessed 1 July 2020].

Kritzer, H.M., 2011. The Antecedents of Disputes: Complaining and Claiming. Oñati Socio-Legal Series [online], 1(6). Available from: http://opo.iisj.net/index.php/osls/article/viewFile/53/225 [Accessed 1 July 2020].

Lee, J., 2014. Two Defining Features of Russian Tort Law: Their Rationale and Legal Effect. Review of Central and East European Law [online], 39(2), 109-143. Available from: https://doi.org/10.1163/15730352-00000015 [Accessed 1 July 2020].

Lenta, 2019. “Deshevle novykh rodit'” Pochemu zhizn', zdorov'ye i svoboda rossiyan stoyat tak malo [Why Do the Life, Health and Liberty of Russians Cost So Little?]. 
Lenta [online], 17 June. Available from: https://lenta.ru/articles/2019/06/17/zhizn [Accessed 23 June 2020].

Lewis, R., and Morris, A., 2012. Tort Law Culture: Image and Reality. Journal of Law and Society [online], 39(4), 562-592. Available from: https://doi.org/10.1111/j.14676478.2012.00600.x [Accessed 1 July 2020].

Lewis, R., Morris, A., and Oliphant, K., 2006. Tort personal injury claims statistics: is there a compensation culture in the United Kingdom? Torts Law Journal [online], 14(2), 158-175. Available from: https://doi.org/10.2139/ssrn.892981 [Accessed 1 July 2020].

Lewis, R.K., 2014. Compensation culture reviewed: incentives to claim and damages levels. Journal of Personal Injury Law [online], 4, 209-225. Available from: https://doi.org/10.2139/ssrn.2467110 [Accessed 1 July 2020].

Markovits, I., 1989. Law and Glasnost': Some Thoughts about the Future of Judicial Review under Socialism. Law \& Society Review [online], 23(3), 399. Available from: https://doi.org/10.2307/3053828 [Accessed 1 July 2020].

Novitsky, I.B., and Luntz, L.A., 1950. General Doctrine of Obligations [Obshhee uchenie ob objazatel'stve]. Moscow: Gosyurizdat.

O'Connell, J., and Carpenter, K., 1983. Payment for Pain and Suffering Through History. Insurance Counsel Journal, 50, 411.

OGF, 2019. Podgotovlena rezoljucija kruglogo stola "Kompensacija moral'nogo ushherba za prichinenie vreda zhizni i zdorov'ju cheloveka". OGF [online], 30 May. Available from: https://civil-forum.ru/news/podgotovlena-rezolyutsiyakruglogo-stola-kompensatsiya-moralnogo-ushcherba-za-prichinenie-vredazhiz.html?sphrase id=7417 [Accessed 23 June 2020].

Osakwe, C., 1979. Examination of the Modern Soviet Law of Torts. Tulane Law Review, 54,1 .

Priel, D., 2014. Tort law for cynics. The Modern Law Review [online], 77(5), 703-731. Available from: https://doi.org/10.1111/1468-2230.12087 [Accessed 1 July 2020].

Rogovich, L., 2005. O vozmeshhenii vreda prichinennogo zhizni i zdorov'ju rabotniku rabotodatelem istoricheskij aspect [On compensation for harm caused to life and health of the employee by the employer historical aspect]. In: A. Shevchenko, Deliktnye objazatel'stva po rossijskomu grazhdanskomu pravu [Tortious obligations according to Russian civil law]. Far Eastern University, 81-108.

Ross, H.L., 1980. Settled Out of Court: The Social Process of Insurance Claims Adjustment. London: Aldine.

Rudden, B., 1967. Soviet Tort Law. New York University Law Review, 42, 583.

Santore, R., and Viard, A.D., 2001. Legal fee restrictions, moral hazard, and attorney rents. The Journal of Law and Economics [online], 44(2), 549-572. Available from: https://www.dallasfed.org/assets/documents/research/papers/1999/wp9912.pdf [Accessed 6 July 2020]. 
Sebok, A.J., 2009. Punitive damages in the United States. In: E. Koziol and V. Wilcox, eds., Punitive Damages: Common Law and Civil Law Perspectives. Vienna: Springer, 155-196.

Shavell, S., 2004. Foundations of Economic Analysis of Law. Cambridge, MA: Harvard University Press.

Shershenevich, G.F., 1911. Uchebnik russkogo grazhdanskogo prava [Russian civil law textbook]. Moscow: Izdanie Br. Bashmakovyh.

Shevchuk, V., and Pleshkov, A., 2001. Avtotransportnoe Strahovanie (ot Istokov do Sovremennosti) [Motor vehicle insurance (from origins to the present)]. Moscow: Ansel-Press.

Siegelbaum, L., 2008. Cars for Comrades: The Life of the Soviet Automobile. Ithaca: Cornell University Press.

Smith, H., 1980. Book Review: Ráspunderea Civilá pentru Daunele Morale [Civil Responsibility for Moral Damages]. By Ioan Albu and Victor Ursa. [Cluj-Napoca: Editura Dacia. 1979]. International and Comparative Law Quarterly [online], 29(2-3), 535-536. Available from: https://doi.org/10.1093/iclqaj/29.2-3.535 [Accessed 1 July 2020].

Solyom, L., 1981. Recent Tendencies in the Law of Tort in Hungary. Acta Juridica, 23, 201.

Sugarman, S.D., 2006. A Comparative Law Look at Pain and Suffering Awards. DePaul Law Review [online], 55(2), 399. Available from: http://via.library.depaul.edu/lawreview/vol55/iss2/7 [Accessed 6 July 2020].

Szpunar, A., 1967. The Law of Tort in the Polish Civil Code. International \& Comparative Law Quarterly [online], 16(1), 86-102. Available from:

https://doi.org/10.1093/iclqaj/16.1.86 [Accessed 1 July 2020].

TASS, 2018. Sud'ja Verhovnogo suda schitaet, chto razmery kompensacij moral'nogo vreda dolzhny byt' vyshe. TASS [online], 20 March. Available from: https://tass.ru/obschestvo/5050216 [Accessed 23 June 2020].

Tay, A.E.S., 1969. The Foundation of Tort Liability in a Socialist Legal System: Fault Versus Social Insurance in Soviet Law. The University of Toronto Law Journal [online], 19, 1. Available from: https://doi.org/10.2307/824972 [Accessed 1 July 2020].

Thompson, C., 1996. Insuring a Brighter Future: The Emerging System of Russian Insurance Law. Houston Journal of International Law, 19, 863.

Vidmar, N., Gross, F., and Rose, M., 1998. Jury awards for medical malpractice and post-verdict adjustments of those awards. DePaul Law Review [online], 48(2), 265. Available from: https://via.library.depaul.edu/law-review/vol48/iss2/6 [Accessed 1 July 2020].

Viscusi, W.K., 2002. Punitive Damages: How Jurors Fail to Promote Efficiency. Harvard Journal on Legislation [online], 39, 139. Available from: 
https://law.vanderbilt.edu/files/archive/229 Punitive Damages.pdf [Accessed 6 July 2020].

Wilcox, V., 2009. Punitive damages in England. In: E. Koziol and V. Wilcox, eds., Punitive Damages: Common Law and Civil Law Perspectives. Vienna: Springer, 7-53.

Wissler, R.L., Hart, A.J., and Saks, M.J., 1999. Decision-making about general damages: A comparison of jurors, judges, and lawyers. Michigan Law Review [online], 98(3), 751-826. Available from: https://repository.law.umich.edu/mlr/vol98/iss3/3 [Accessed 6 July 2020].

Zeits, A., 1927. Vozmeschenie moralnogo vreda po sovetskomu pravu [Compensation of moral damages according to Soviet law]. Ezhenedelnik sovetskoy yustitsii, 47, 1465-1466.

Zweigert, K., and Kötz, H., 1998. Introduction to Comparative Law. Oxford University Press.

\section{Laws and statutes}

Civil Code of the Russian Federation of 30 November 1994.

Civil Code of the Russian Soviet Federated Socialist Republic (1964). (Trans.: W. Gray and R. Stults) [online]. Ann Arbor: University of Michigan Law School. Available from: https://repository.law.umich.edu/books [Accessed 6 July 2020].

Federal Law N 193-F of 27 July 2010. On Alternative Dispute Resolution (Mediation).

Law of the Russian Federation N 2300-1 of 7 February 1992. On Protection of Consumer Rights.

Law of the Russian Federation N 40-FZ of 25 April 2002. On Compulsory Liability Insurance of Motor Vehicle Owners.

Law of the Russian Federation N 52-FZ of 28 March 1998. On Compulsory State Life and Health Insurance for Military Personnel, Citizens Called Up for Military Training, Ordinary and Senior Officers of The Internal Affairs Bodies of The Russian Federation, the State Fire Service, Employees of Institutions and Bodies of the Penal System, Members of the National Guard of the Russian Federation.

Law of the Russian Federation N 67-FZ of 14 June 2012. On Compulsory Insurance of Civil Liability of a Carrier for Causing Harm to Life, Health, Property of Passengers and On the Procedure for Compensation for Such Damage Caused during Transportation of Passengers by Subway.

Law of the Russian Federation of 1 July 2003. On Compulsory Motor Third Party Liability Insurance.

Law of the Russian Federation of N 125-FZ of 24 July 1998. On Compulsory Social Insurance against Industrial Accidents and Occupational Diseases.

Statute of the Soviet Union on Press and other Mass Media of 12 June 1990.

Statute on Consumer Rights Protection of 7 February 1992.

The Fundamentals of Civil Law of the Soviet Union of 31 May 1991. 


\section{Case law}

Moscow Region Cassation Court, Cassation Judgment no 361 of 5 July 2017.

Novosibirsk Regional Appeal Court, 1 August 2017, Case no 33-7340/2017.

Resolution of Plenum of the Supreme Court of the Russian Federation on Some Issues of the Application of Legislation on Moral Damages of 20 December 1994.

Resolution of Plenum of the Supreme Court of the Russian Federation on Application by Courts the Legislation Regulating the Obligations Based on Causing Harm to Health and Life of 26 January 2010.

Resolution of the Plenum of the Supreme Court of the Russian Federation N 17 of 28 June 2012. On the Consideration of Civil Cases in Disputes on the Protection of Consumer Rights.

Saha (Yakutia) Regional Appeal Court, 4 September 2017, Case no 33-3400/2017.

Sverdlovsk Regional Appeal Court, 12 October 2017, Case nº 33-16487/2017. 